\title{
A Gender Approach to Militancy (Extremism) in Pakistan -A Case Study of North-Western Region
}

\author{
Shahid Dilawar \\ Department of International Relation \\ National Defense University Islamabad \\ Asghar Khan \\ Department of Regional Studies \\ University of Peshawar \\ Muhammad Nawaz Khan Jadoon \\ Area Study Centre \\ Russia, China \& Central Asia University of Peshawar
}

\begin{abstract}
The agenda of gender and security in the debate of international relations has much to achieve yet. The notion is based on normative differences of feminism and realism. The former is a flag bearer of feminist agenda of political studies and the latter is a leading International Relations paradigm. There have been many case studies and accounts in which women as victims of conflicts are studied and their plights are analyzed, however, the role of women as 'security agent' had hardly been previously touched. The gender inequality worsens the situation in Pakistani society as it promotes radical/extremist tendency which subsequently poses immense security challenges to the social fabric. Due to lack of research on this particular issue, the study has been opted for further exploration. Pakistan being at the forefront in the war against terror since its onset in 2001, has predominantly a military based security agenda. However, the country with $52 \%$ of female population, makes it an appropriate case study to understand security and gender. This paper pertains to some conflict hit areas of Pakistan where women role has been analyzed as security agent. This paper is an attempt to explore and analyses the theoretical and academic debate of gender and security with particular reference to North-Western Pakistan.
\end{abstract}

Keywords: Security, Extremism, Realism, Gender, Feminism, Terrorism, Swat, Tribal Areas.

$$
\begin{aligned}
& \text { تلخيص }
\end{aligned}
$$

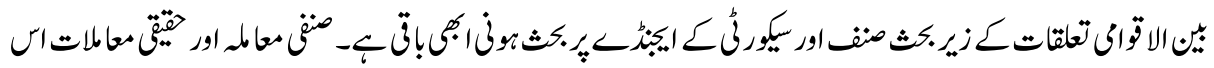

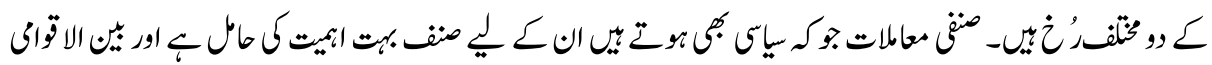

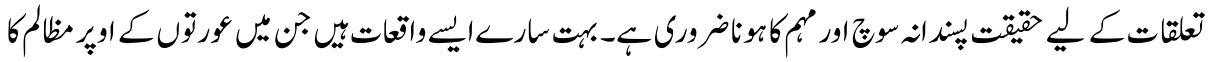




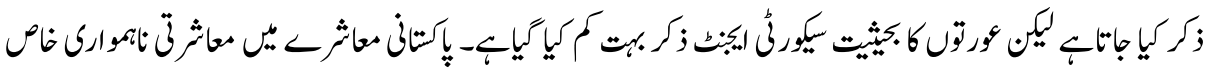

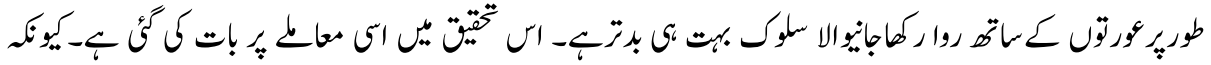

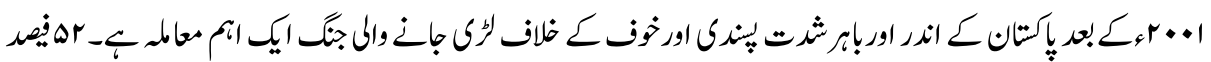

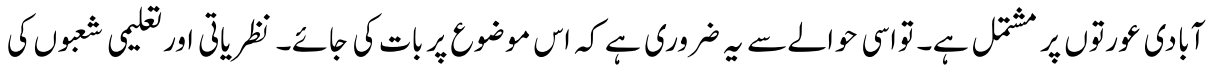

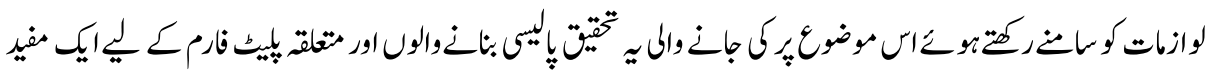

$$
\begin{aligned}
& \text { - }
\end{aligned}
$$

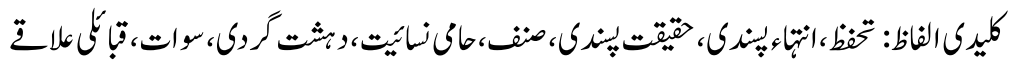

\section{Introduction}

This paper analyses discussion on gender and security within the context of sociopolitical and economic role of women, their conditions and its implications for security in any state and in particularly in Pakistani context. Further, the concept of gender and security has been discussed under the agenda of comprehensive security, inclusive security and critical security studies. The word 'gender' itself is a representation of some age old cultural practices in a society which differentiate men from women, essentially and have become a normative value of that society (Acker, 1990). The gender-based research and analyses has been mainly embraced by the feminist school of thought. The gender-based inequality, its social cognitions and constructs stand generally at the bottom of state security. It is believed that there is a direct relationship between gender and human security and thus an indirect relationship between state security and gender (in)equality in a country. The concept of interrelation between security and gender was voiced in international declarations and conventions which subsequently have evolved in different world women conferences. The UNSC Resolution 1325 not only acknowledges vulnerability of women but also their role in the situations of conflicts and peace keeping. The Resolution also urges that "all UN member countries should ensure the equal participation of women, at all decision-making levels in conflict resolution and peace processes" (UNSCR, 2000).

The concept of gender was academically introduced first time in 1971 in Sex and Gender published by Oakley. It was said that poverty and patriarchy are the main reasons behind women oppression in the world. The term patriarchy is referred to a complete set of social practices where male dominance is the norm or custom (Bhasin, 2000). It means a vertical, hierarchical power relationship by which men enjoy more control of the life, possessions, decisions, divisions and even control on women. In some societies patriarchic systems have resulted in inevitable inferiority of the women to the men. Ms. 
Bhasin is of the view that patriarchic practices have 'equivalents' in South Asia which are called Pidarshahi in Urdu language and Pitrasatta in Hindi means rule of father (Bhasin, 2000).Patriarchal ideologies are deep rooted even in modern cultural transformations. The practices encapsulate the political, economic, and socio cultural structures of the world. The religious and legal structures around the world are also patriarchic in nature (Kumar, 2011).

The level of gender equality (and inequality) in a society is determined and affected by different social institutions; and it becomes more evident if one considers society of Pakistan. The inequality is cultural and structurally rooted concept about social, economic and political roles of a woman. The behaviors of market, state institutions, family, neighbors and even literature towards women are highly restricted, linear and to some extent biased. Little has been done to raise capabilities of women in achieving self-actualization.

During revision of dominant realist paradigm of security in 1960s, the gender discourse was overlooked as an important factor in state security analysis. It was in 1980s, various feminist researches and writings emphasized gender aspect in security which brought it to a limelight (Tickner, 1992). The researchers and policy makers have tried to prove that security is more than military concept of security (Terriff, et al, 1999). Though military security is still present and significant but the alternative aspects of security have also got importance. However, in these alternative aspects, the aspect of gender is still under recognized and needs more emphasis (Kennedy-Pipe, 2007).

The route of analyzing security, peace and conflict through prism of feminism requires an essential understanding of realism and feminism. Realism, among all other theories of Political Science and International Relations, is compared with feminism on three ground realities. These three ground realities between feminism and realism are: Realism has been and still is predominantly a patriarchic theoretical paradigm, promoting male and military oriented version of security, feminism as a comparatively new comer in the field has more challenge of rationale and logic from realist school than any other school of thought and Realism in most of its forms, shades and sub-schools is state centric and security oriented, which primarily ignores feminism as a school of thought. Thus according to many feminists, the theory and practice in International Relations have been patriarchic (Enloe, 2000: 11).

Gender inequality enhances sense of vulnerability and erodes human security. Prolonged cultural gender inequality deepens structures of exclusions in society. It is observed and proven empirically that either there is not sufficient awareness about significance of gender equality or instead of awareness, there are policy lapses and institutional failures to properly tackle gender issues. Similarly, there are customary practices of inequality which are indoctrinated both in men and women of the society (McCabe,et al. 2011). 
In the context of Pakistan, women are playing role in the security which is a ground reality. Women are not only the victims; they are instigators, actors and resolutely agents also. Their role may not be identified at political front as such but at social front and in the field work of post crisis/conflict scenarios it is an evident. The gender inequality worsens the situation in Pakistani society as it promotes radical/extremist tendency which subsequently poses immense security challenges to the social fabric. In Pakistani society, women are the victims of inequality and internalization of structural violence. Women are often denied right to inheritance and property. Similarly, there is absence of available and accessible protection and subsequent justice to women. This patriarchic structure has wider security ramifications for the whole nation. The patriarchal structures make development protracted and also help perpetuate the enduring gaps. The social structure is patriarchal in Pakistani society where men have privileges: social values are attached to men's work, men have control over resources, having decision-making authority, having mobility and non-harassment. While women lack these privileges and thus lack access to adequate education, training, health, nutrition, decision-making powers and are less able to contribute effectively in development (Haq, 2001).

\section{Research Question and Methodology}

This paper attempts to understand correlation of gender and extremism in contemporary politics within the context of North-Western Pakistan. The basic research question on which the whole edifice of the research work is based is, "whether gender inequality in Pakistani society promotes radical/extremist tendency which subsequently poses security challenge to the state?'Further, the paper explores the interrelation between security and gender in the conflict affected area (Swat District) of North-Western Pakistan. The militant organizations and women, vice versa, had established links through FM radio station with one another. The marginalization of women had been exploited by the militant (extremist) organizations in their favor.

To investigate this claim, a mixed method approach was adopted where both primary and secondary data was collected. Quantitative data was collected through questionnaire, while qualitative data was collected through focus group discussions and participant observations. Secondary data was collected by reviewing the published sources. ${ }^{1}$

\section{Literature Review}

Gender was not considered a relevant value of politics and strategy till 1980s of the major theoretical debate of Positivism-Post positivism. There was an attempt to relate politics and gender at first in 1980s. The Chief of Staff at White House recorded his statement in front of the reporter of Washington Post that women were not going to comprehend at issues of missiles and wars (Tickner 1992). The Chief also said that many of the women 
would not take interest in Afghanistan issue or other political matters. With this mindset dominating Whitehouse matters, the feminists asserted role of women in international politics. The Millennium issue on "Women and International Relations was published in 1988" which became an initiative for future academic development of feminist approach in the field of International Relations (Bormann and Sheehan, 2010). Enloe's (2000) work was a watershed approach in the field of Politics and its agenda. It gave a new ground to study and analyze war, economy and other issues from the perspective of gender. It hinted on the issues of methodology also. The work of Cynthia Enloe mainly highlights gender dimension in the main field of politics (Gustavsson \&Tallberg, 2006).

The concept of security was revised to be more inclusive, non-traditional and comprehensive in 2000s. The debate between IR scholars and feminists was characterized by Robert Keohane. The effort was based upon the reservations of feminist school of thought regarding language and content of existing IR literature which was 'gendered' towards men. It was followed by the wave of writing and research of feminists urging revision of IR literature to balance footprint of each gender.

A link established directly between security, conflict resolution and gender in 2000s. Although in Europe and West, the data is produced on the relationship of IR, security, feminism and conflict but security remains an agenda of state craft and military, politics is dominatingly a man's game to play. The UNSC Resolutions 1325 and 1820 obliged UNSC and UN member states to essentially include women on peace talks, negotiations, conflict resolution and many more related such activities. The World Bank, IMF and UN had unanimously made gender as a salient feature for global governance. The realist school of thought is closer to feminism as far as methods of acquiring or securing knowledge is concerned. Both the 'isms' bridge ontology and epistemology in their knowledge building. Realism has remained a male oriented school while feminism wants to bridge the gap by emphasizing the role of women both ontologically and epistemologically (Kronsell, 2006).As women are the most insecure in a conflict situation, feminism, therefore, also explores the role of women in conflict situation. Pakistan being at the forefront in the war against terror since its onset in 2001, has predominantly a military based security agenda. However, the country with $52 \%$ of female population, makes it an appropriate case study to understand security and gender.

\section{Status of Woman in Pakistan}

In Pakistan, the gender bigotry is woven in the social fabric of the state and limits the role of women to domestication or subsidiary positions. The invisibility of women in the economic sphere in Pakistan and its impact on women is alarming and mischievous (Kronsell, 2006: 3). Mahbub-ul-Haq's played pivotal role in highlighting the importance of gender equality in economic development of the country. He changed the debate at 
very fundamental level. He asserted that the process of human society and human development, if not engendered it will be greatly endangered. He conceptualized gender inequality by claiming that "No society has ever liberated itself economically, politically, or socially without a sound base of educated women" (Haq, 2001). He further told, "While growing up in South Asia is a perpetual struggle, to be a woman in this region is to be a non-person. Women bear the greatest burden of human deprivation in South Asia" (Haq, 2001). Despite being a signatory of CEDAW, the education, health, social, legal, political, education and economic systems in Pakistan is heavily prejudiced against women (Stout, 2004: 4). The female literacy rate and educational indicators are very appalling when compared it to the other part of the world. It is ironic that even less number of the females reach level of higher education or technical education (Stout, 2004: 5). The health sector has not been kinder to women in this part of the world, there is a volume of female population who don't have access to even very basic health facilities. The ultimate discrimination in above mentioned areas has resulted in invisibility or inconsequential presence of women in governance structures and decision-making bodies at different levels of politics. This situation is also internalized by the women themselves as they have been indoctrinated throughout their childhood and youth to be obedient towards males of the family without questioning their logic. They are submitted to obedience in the name of protectionism, carrying honor of the family on their shoulders buying the notion that they are more or less a property to the males of the family. In most illiterate part of the country, the practices like honor killings (Karo-Kari) take place to avenge family 'honour when a woman violates tribal or cultural norms and traditions.

Politically, although all major political parties of Pakistan have their women wings, on political perspective, women in Pakistan are far lagging behind because their women participation in party hierarchies remains limited. The main reason of these wings is to mobilize women voters during elections and not to pragmatically address role of women in political processes. Their presence is merely symbolic or cosmetic as they have hardly ever influenced party agendas. As a result of under representation and being a marginalized section of the society, they are been prone to extremist tendencies. Taking example of extreme north western region of Pakistan (now called newly Merged Tribal Districts-previously called FATA recently merged with KP under $25^{\text {th }}$ constitutional Amendment- 2018)is worst hit by extremism, religious fundamentalism and terrorism, maintains a 3\% female's literacy rate which is among the lowest in the world where the dropout of the girls from schools also stands at 70\% (Khan, 2012: 7). The women of FATA before 2018 were not considered under litigation impact of laws for women in the mainland of Pakistan. The female illiteracy rate had obviously contributed their disempowerment and marginalization in the society which had greater impact in the socialization and upbringing of the children as well. As a result, children in the area lack dispassionate understanding of religious values of tolerance, self-restraint, selflessness and above all a contextualized and dispassionate understanding of religion. As a result, 
the women of tribal areas could hardly raise their children with the values of tolerance, self-restraint, altruism and above all a contextualized and dispassionate understanding of religion. As half of the population of FATA comprising women has been out of the Economic development and political process, its natural consequence is the creation of a huge political vacuum. In case of FATA, the relationship between the political vacuum and the rise of extremism and terrorism in the name of Islam is most important (Cordesman, 2017). If women of FATA were educated and empowered they would know the tool of peaceful resolution of disputes and the same understanding could have been transferred to their children which could be proved as first line of defense against terrorism and extremism. This fact has been confirmed by an educated young boy of Bajaur Agency. Irfan Ullah told, "If women in FATA were empowered and educated, chances were that they would ensure their children not to join the militants"(Field interview). But on the other side, Taliban have banned girls 'education in the areas under their control and this further caused an increase in extremism and terrorism in FATA (Khan, 2011).

Similarly, the displacements of the population during 2009 in Swat militant crisis or 2010 floods aptly highlighted the dearth of policy making for gender equality and huge gaps in bureaucratic practices in this regard. The displaced population was mainly women and children and worst effected too. The displaced women and their children were without food or medicine in majority cases. The most awful fact was that because of gender stereotypes and conservative cultural norms, the female were unable to get registered at the camps, no registration means no head count in donations and eventual deprivation. The security risks arose when female who had CNICs came without their pictures on the cards. In many cases the complete families were turned away from camps because at the times of crisis they were being headed by a lady and lady either did not have a CNIC or did not have her picture on it (UNDP 2010, 210 - 11).

\section{Gender-Violence-Extremism Correlation}

The correlation of gender and violence does exist since centuries, it is as old as violence and power. The academia, research, feminist movement or other actors of gender politics started documenting the correlation of violence and gender much later, in $19^{\text {th }}$ century. The victimization of females during times of crisis, conflict or war has been a known phenomenon now. Males or females, once gone through trauma have rich chances to become violent. They take revenge or get satisfaction by causing pain to others, it makes them feel powerful and in control. It sooths their nerves. Trauma victims sometimes join radical, terrorist or extremist groups in minor or major capacity. These groups provide them a sense of gain, protection, money and above all security from many factors. The previously victimized people try to repair their damaged self-image. There is a correlation between social factors and violent ideologies. Some social realities pave the 
way for violent terrorist ideologies and the mechanisms. An individual living in an oppressive society has more chances toward extremist tendencies (Ziemke 2006). This claim has been supported by the respondents during field survey in North-Western Pakistan (Swat region) by showing agreement $(75.5 \%$,) with this statement. Violence is basically learned through modeling within the family and then society (Stout, 2004).

\section{Results and Discussion}

The failed attempt of Talibanizing Swat valley is most relevant study to understand correlation of gender and extremism in contemporary politics. The Swat militancy which started getting roots in 2007 and was curbed by a military operation in 2009 had have females not only as victims but also as soft power means, networking channel and ideological partner. The role of females of Swat in proliferating and deepening influence of TTP in the area remained ironically significant.

The militancy in Swat not only involuntarily promoted by the women, but had also hardest consequences for them. In no time they formed a relationship of mentorship with the militant commander Fazlullah (commonly known as Mullah Radio). The field data gathered from North-Western Pakistan (Swat) support this claim that in this way the militant's access to women led to expansion and support to their ideology (79\% Agreed) Table -1 . He became their father and brother like figure who used to guide them on daily life issues in the light of Islam. The popularity of his talk was discussed and quoted in different social get together of the females. In front of the males of family his religious valor and wisdom was discussed. The females of the families soon started prompting their male relatives to take part in self-proclaimed Jihad by militant commander Fazlullah. This claim was supported by significant number of respondents $(72 \%$ agreed) that the women led to persuade their husband and sons to join the militants in jihad Table -1 .

Table - 1: Field Data on Women and Extremism

\begin{tabular}{|l|l|c|c|c|c|}
\hline \multicolumn{1}{|c|}{ Question/ Indicator } & $\begin{array}{c}\text { Response } \\
\text { Rate }\end{array}$ & Agree & Disagree & $\begin{array}{c}\text { Don't } \\
\text { Know }\end{array}$ & Total \\
\hline $\begin{array}{l}\text { Militants' access to marginalized } \\
\text { section of society (women) led to the } \\
\text { expansion and support of their } \\
\text { ideology }\end{array}$ & Frequency & 158 & 22 & 20 & 200 \\
\hline $\begin{array}{l}\text { Women led to persuade their } \\
\text { husband and sons to join the } \\
\text { militants in jihad }\end{array}$ & Percent & 79.00 & 11.00 & 10.00 & 100 \\
\cline { 2 - 6 } $\begin{array}{l}\text { Marginalization of women led to } \\
\text { extremism and abnormal psychology } \\
\text { of the family }\end{array}$ & Fercent & 144 & 39 & 17 & 200 \\
\cline { 2 - 6 } & Frequency & 151 & 36 & 13 & 200 \\
\hline
\end{tabular}


They had remained confined, away from exact required understanding of politics or the long term implications of what they were doing. They had remained disempowered and discriminated for a long period of time in Swat and now they through their nexus with the militant commander Fazalullah felt empowered. They felt elated as they could speak to him on hot line at the FM station and he lent them his ears like an understanding mother, friend or brother, It also provided them an opportunity to discuss matters with the leaders. The militants very cleverly obtained the unquestioned loyalties of the women and induced provoked Quranic translations and messages in them. The women unwillingly became bearers of the messages of militants in their circles. Consequently Mullah Fazalullah had support of the female population for his extremist policies (Aziz, 2010).

The women in Swat had have poor education and their thinking structures were not tailored to distinguish between right and wrong where Quran was involved. In their view they were serving the ultimate cause of Islam by supporting Mullah Fazalullah (Aziz 2010). They in all their illiteracy, naïve political statures and in-visionary life styles were convinced that the Taliban would reinstate the Golden Age of Islam. They were encouraged to contribute money and were also convinced to persuade their husbands and sons to join the terrorists in Jihad against Pakistan in view of the fact that the government supported the US (the infidels). Furthermore, the Taliban encouraged women to make telephonic calls to the radio station (Aziz, 2010).The aspect of their illiteracy is emphasized here because when they were taught some religious values in the name of ALLAH they committedly followed the instructions of Islam. In a sense, a woman with a radio became captive to the constant haranguing delivered over Mullah Radio. If these ladies could have been educated and visionary they would have denied listening to extremist speeches of Fazalullah at first place. Therefore a woman, disempowered, confined in home, illiterate with lack of exposure became a recipe of success for the militants. She was a willing captive. The next step was prompting women of swat to provide financial assistance. So they donated whole heartedly. Many respondents in this study when interviewed said that they gave their jewelry, money and in one case, a lady even gave her car to the Taliban. There were found some broadcasts where women were encouraged to donate, to ask their male relatives to join militancy and in some cases they were asked and encouraged to hit Pak military forces either (Aziz, 2010). Thus the Taliban dramatically provided a stage interplay between newly found roles and identities and used tactics of mind control to their interest. Although the initial softening of the image of Taliban was done through soft talk, the subsequent takeover of the female judgment by banning them from watching other channels thus a complete take-over of mind became possible. Once Taliban had mind control over judgment of the females they gradually created a guilt in their minds and stripped her self-esteem in a way that she started considering herself an ultimate evil entity. At this stage, it allowed the terrorists to super impose another identity on her that was favorable to militants. This is what gradually happened with the women of Swat. When one has guilt, one wants to be 
something of value, wants to do more, this was where Taliban dictated. Then there was a new super identity imposed over the women. Their very existence as an individual was destroyed and challenged when Taliban prohibited them to go out of the house without a male partner. The girls' schools and women education colleges were destroyed, burnt and female education totally banned. The access to medical facilities was now limited to certain conditions for the women of Swat. The women were confused than ever before, the newly achieved confidence was gone and replaced by a guilt, a politically transformed version of Islam was given to her and she slipped into a guilt complex. The women now wanted to get rid of this psychological burden and tried to donate more. As the women were experiencing identity crisis, an inner conflict, they also had joined a criminal network. Their donations to a banned organization made them accomplice to the crime against the state. On the other hand, when she started convincing her husband/sons to help the militants she was also facilitating criminal acts (Khan\& Aftab, 2009).Though the causes of militancy in Swat are multiple, yet amongst the many factors that are at the core of extremist violence, the frequent occurrence of marginalization of women and its negative implications for the whole of the family which generally led to the criminalization of society is more evident. Marginalization is pernicious since it takes away the identity of a person and could be lethally dangerous.

\section{Conclusions}

The struggle of feminism in Pakistan is multi-dimensional, it is to eradicate social and structural violence against women to ensure that women are protected from militants/ extremist forces, as well as from violence and cruel traditional practices to enhance their role as securitizing agent. Aggression in any gender is not innate; it is socially constructed and indoctrinated. Women are kept weak, unexposed to the outer environment and many times are left out of any political debates at home. They are considered to follow the males of their family in the name of honor and respect. Women though have potential to play a significant role in the security of their country and values but are themselves insecure or under secured. The discourse made it clear that violence/discrimination against women promote radical tendencies in the male member of the family from the very beginning of their childhood and the family itself becomes prone to indoctrination and intolerance which proved to be the breeding ground for militancy and extremism in larger context of society. When the balance between male and female members in a family is disturbed, the feelings of relative deprivation, social exclusion, injustices are cropped which creates a vicious cycle in the family. This vicious cycle of discrimination, social exclusion make the whole family very much receptive to the indoctrination of extremist ideologies which is often manifested in the shape of militancy and insurgencies and swat is the classical example in this regard. In the reconstruction and rehabilitation phase of Swat after militancy, the resilience of women in Swat, their efforts at rehabilitation and their courageous leadership in their 
communities is praise worthy. But the irony is that the policymakers have not fully realized or capitalize on the knowledge, experience, and collective power of women and their peace building potential.

\section{Recommendations}

It is both intriguing and dichotomous that militant factors utilized gender inequality, conservatism and significance of female population to their advantage. The tactic was soft power (radio) and the ultimate goal was to deepen extremism, finance extremism and perpetuate it. It leaves some lessons for the government of Pakistan to be drawn. It is in addition to the facts that conservatism, conflict and crisis have already affected socioeconomic identity of women in Pakistan. It is essential to ensure female participation in peace and security related decision making at all levels. If woman can play a role in radicalization of a society she can also play a role in de-radicalization of a society as well. On the basis of Swat Valley scenario, in the security history of Pakistan, the paper gives the following recommendations:

- Females should be literate and politically aware as being illiterate and a-political has comprehensive security implications for them, their family and state at large.

- Females can play smart brains for the security of the country and if not taken into the loop by the state they may become means for the adversaries.

- Women from any fields, sector of life are valuable for the security of the country, they can be reached out through soft means of communication.

- It is imperative that Pakistan should develop strong institutional structures based on gender equality. For this purpose, media should take responsibility to improve role of women in Pakistan instead of portraying sensational and stereotypical roles of the women.

- The presence of few articles in constitution, ratification of CEDAW and licensing of some women groups to operate in Pakistan is not sufficient. No social structures can be transformed without proactive government policies. The securitization of women rights is a political agenda having deeper correlation with the social fabrics of society. There should not only be laws but also need mechanisms and perception management.

\section{End Notes}

1 The primary data utilized in this paper obtained from the research study conducted for the author M.Phil research degree in 2010-11 submitted to National Defense University (NDU) Islamabad. The sample size adopted for this study was 200 respondents (on equality basis 100 female and 100 male) obtained through simple random method. 


\section{References}

Acker, Joan, (1990). Hierarchies, Jobs, Bodies: ATheory of Gendered Organization, Journal of Gender \& Society, vol.4:2, pp.139-158.

Aziz, Khalid (2010). SWAT: The Main Causes of the Breakdown of Governance and Rise of Militancy. Peshawar: Regional Institute of Policy Research \& Training (RIPORT).

Aziz, Khalid (2010). SWAT: The Main Causes of the Breakdown of Governance and Rise of Militancy. Peshawar: Regional Institute of Policy Research \& Training (RIPORT).

Bhasin, Kamla (2000), Understanding Gender. New Delhi: Pauls Press.

Bormann, Natalie \& Michael Sheehan in Laura Sjoberg (Ed.), (2010). Gender and International Security: Feminist Perspectives. London: Rutledge.

Enloe, Cynthia, (2000). Bananas, Beaches and Bases: Making Feminist Sense of International Politics. California: University of California Press.

Fact box, "the world's most dangerous countries for women", the Reuters, 15 June 2011.

Government of Khyber Pakhtunkhwa (2011). Statistics of the Provincial Government of Khyber Pakhtunkhwa. Retrieved from: http://kp.gov.pk/page/ swatdistrictdemographics

Gustavsson, Jakob and Jonas, Tallberg. (2006). "Inledning" in JakobGustavsson and Jonas Tallberg (ed.) Internationellarelationer. Danmark: Studentlitteratur.

Haq, Mahbubul, (2001). Human Development in South Asia, the Gender Question. Oxford: Oxford University Press.

Kennedy-Pipe, Caroline (2007). Gender and Security in Alan Collins (ed.) Contemporary Security Studies. Oxford: Oxford University Press.

Khan, Ahmad (May 6, 2011). Taliban Fear Forcing Tribal Girls to Join Seminaries: HRCP. Peshawar. Dawn.

Khan, Azam \&Aftab Khan, (June 2009). Inequality and the Militant Threat in Pakistan, Conflict \& Peace Studies, vol.2:2, p.40. 
Khan, Mariyam A. (2015). Women and FATA Conflict: Unfulfilled Promises. Peshawar: CAMP Organization Publishing.

Khan, NailaAman (2012). Socio Economic and Political Status of Women in FATA- The Process of Development and Phenomenon of Militancy, TIGAH, A Journal of Peace and Development, vol.2:1, p.7.

Khan, R. (2012). Extremism Terrorism in the Name of Islam in Pak: Causes \& Counterstrategy. Ph.D Dissertation Submitted to University of Peshawar.

Kronsell, Annica (2006). Feminism in Jacob Gustavsson and Jonas Tallberg (ed.) Internationella Relations. Danmark: Studentlitteratur.

Kumar, R. (2011, May 6). Gender Bias Found in Kids. Hindustan Times, p.5.

Stout, Chris E. (2004). Psychology of Terrorism: Coping with the Continuing Threat. US: Praeger Publishers/Greenwood Publishing Group.

Stout, Chris E. (Ed.) (2004). Psychology of Terrorism: Coping with the Continuing Threat. New York: Praeger Publishers.

Terriff, Terry, Stuart Croft, Lucy James \&Patrick M. Morgan (1999). Security Studies Today. Cambridge: Polity Press.

Tickner, Ann J. (1992). Gender in International Relations - Feminist Perspectives on Achieving Global Security. New York: Colombia University Press.

Tickner, J. Ann, (1992). Gender in International Relations Feminist Perspectives on Achieving Global Security. New York: Columbia University Press.

UNDP (October 2010). The Human Cost of Flood in Pakistan. Islamabad, Pakistan.

United Nations Security Council Resolution 1325, Available from http://www.un.org/womenwatch/osagi/wps/\#resolution

Ziemke, Caroline F. "Perceived Oppression and Relative Deprivation: Social Factors Contributing to Terrorism', in Joseph McMillan (ed.), (2006). "In The same light as slavery" Building a Global Antiterrorist Consensus. Washington, DC: National Defence University Press. 
Mccabe, J., Fairchild, E., Grauerholz, L., Pescosolido, B. \& Tope, D. (2011). Gender in Twentieth-Century Children's Books: Patterns of Disparity in Titles and Central Characters. Gender and Society, 25(2), 197-226. Retrieved from: http://www.jstor.org/stable/23044136

Cordesman, Anthony H. (2017), Islam and the Patterns in Terrorism and Violent Extremism. (Working Draft). Ottawa: Center for Strategic and International Studies, Retrieved from (https://www.csis.org/analysis/islam-and-patternsterrorism-and-violent-extremism)

Shahid Dilawar is Ph.D Scholar in the Department of International Relation, National Defense University Islamabad.

Asghar Khan is Lecturer in the Department of Regional Studies, University of Peshawar.

Muhammad Nawaz Khan Jadoon is Ph.D Scholar in the Area Study Centre, Russia, China \& Central Asia University of Peshawar. 